Keywords: Tritium

Polymers

Radiation Damage

Electrically conductive polymers

Retention - Permanent

\title{
Effects of Tritium Gas Exposure on the Glass Transition Temperature of EPDM Elastomer and on the Conductivity of Polyaniline
}

\author{
Elliot A. Clark, Marie C. Kane
}

Publication Date: 12 December 2008

Savannah River National Laboratory

Savannah River Nuclear Solutions

Aiken, SC 29808

Prepared for the U.S. Department of Energy Under

Contract Number DE-AC09-08SR22470

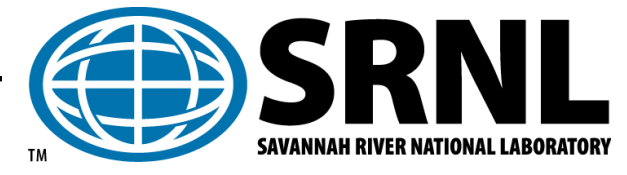




\section{DISCLAIMER}

This work was prepared under an agreement with and funded by the U.S. Government. Neither the U. S. Government or its employees, nor any of its contractors, subcontractors or their employees, makes any express or implied:

1. warranty or assumes any legal liability for the accuracy, completeness, or for the use or results of such use of any information, product, or process disclosed; or

2. representation that such use or results of such use would not infringe privately owned rights; or 3. endorsement or recommendation of any specifically identified commercial product, process, or service. Any views and opinions of authors expressed in this work do not necessarily state or reflect those of the United States Government, or its contractors, or subcontractors.

Printed in the United States of America

Prepared for

U.S. Department of Energy 
CONTENTS

Page

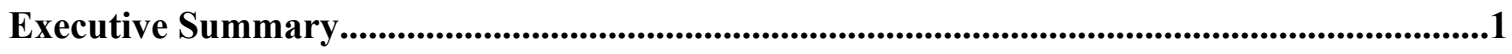

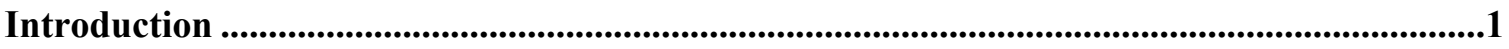

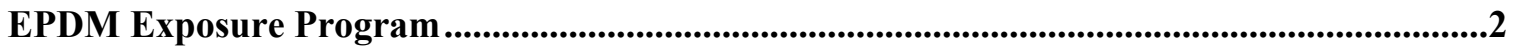

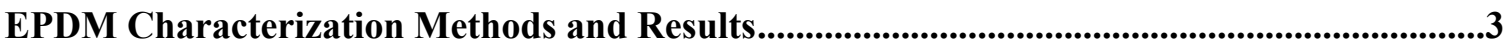

Density .................................................................................................................................................................3

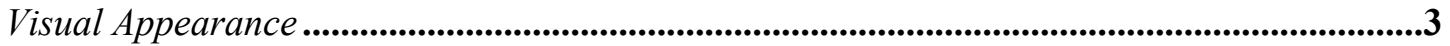

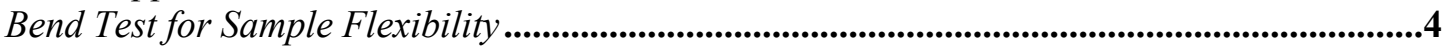

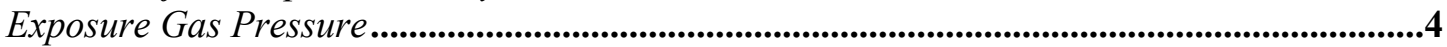

Exposure Gas Composition.......................................................................................................................5

Dynamic Mechanical Analysis- Testing Details ........................................................................6.6

Dynamic Mechanical Analysis- Results .........................................................................................6

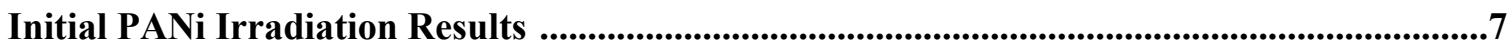

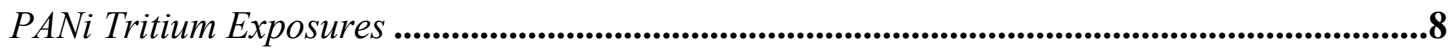

Summary and Conclusions ............................................................................................................

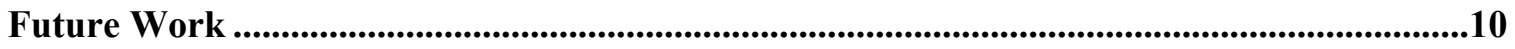

References ............................................................................................................................................10

Figures ...............................................................................................................................................................11 


\section{TABLES}

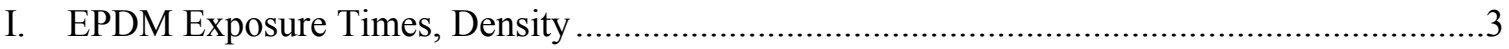

II. Total Gas Pressure in Containers at End of Exposure …......................................................

III. Predicted Pressure Increase Rate, Estimated Pressure after One Year, and Time to reach

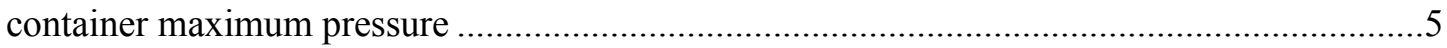

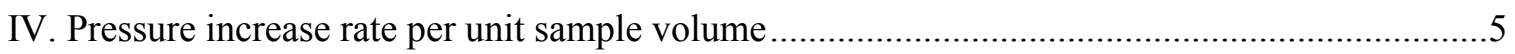

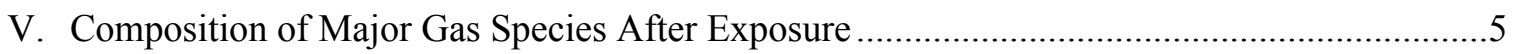

VI. Glass Transition Temperature of EPDM Formulations. ........................................................

VII. List of PANi Exposure Tests, Exposure Time, Pressure..........................................................

FIGURES $\quad$ Page

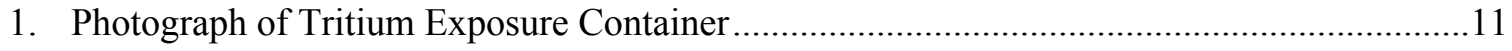

2. Photograph of Unfilled Nordel ${ }^{\mathrm{TM}}$ sample after tritium exposure ..........................................11

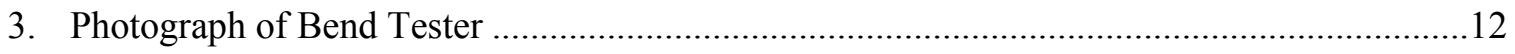

4. Photograph of unfilled Royalene ${ }^{\circledR}$ sample after tritium exposure .........................................12

5. Mole percent of species in gas, species shown by mass/charge ratio and formula

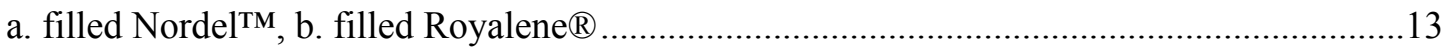

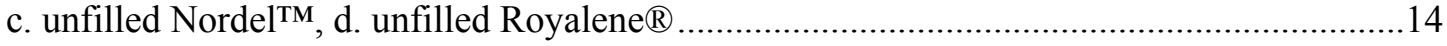

6. Storage modulus, loss modulus, and $\tan \delta$ of filled Nordel ${ }^{\mathrm{TM}}$ with increasing temperature $\ldots . .15$

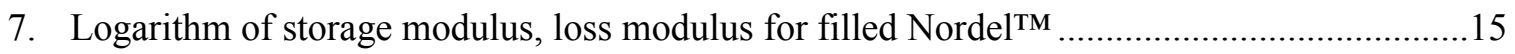

8. Storage modulus and loss modulus of filled Nordel ${ }^{\mathrm{TM}}$ with increasing temperature- two

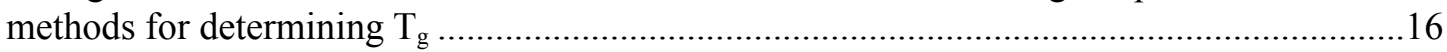

9. Glass Transition Temperature of EPDM formulations with increasing tritium exposure time

10. Surface conductivity of two types of polyaniline as a function of total dose of ${ }^{60} \mathrm{Co}$ gamma; and surface conductivity of two types of polyaniline as a function of time exposed to UV light at $168 \mathrm{~mW}$ 


\section{Effects of Tritium Gas Exposure on the Glass Transition Temperature of EPDM Elastomer and on the Conductivity of Polyaniline}

\section{EXECUTIVE SUMMARY}

Four formulations of EPDM (ethylene-propylene diene monomer) elastomer were exposed to tritium gas initially at one atmosphere and ambient temperature for between three and four months in closed containers. Material properties that were characterized include density, volume, mass, appearance, flexibility, and dynamic mechanical properties. The glass transition temperature was determined by analysis of the dynamic mechanical property data per ASTM standards. EPDM samples released significant amounts of gas when exposed to tritium, and the glass transition temperature increased by about $3^{\circ} \mathrm{C}$. during the exposure.

Effects of ultraviolet and gamma irradiation on the surface electrical conductivity of two types of polyaniline films are also documented as complementary results to planned tritium exposures. Future work will determine the effects of tritium gas exposure on the electrical conductivity of polyaniline films, to demonstrate whether such films can be used as a sensor to detect tritium. Surface conductivity was significantly reduced by irradiation with both gamma rays and ultraviolet light. The results of the gamma and UV experiments will be correlated with the tritium exposure results.

\section{INTRODUCTION}

The unique properties of polymers make them indispensable for certain parts in tritium gas transfer systems. Specifically, the resiliency of elastomers is ideal for sealing surfaces, for example in valves. EPDM (ethylene propylene diene class-M rubber), initially developed in the $1960 \mathrm{~s}$, is a hydrocarbon polymer used extensively for sealing applications. EPDM is used for its excellent combination of properties including a wide operating temperature range, radiation resistance, aging resistance, and good mechanical properties. This study characterizes effects of tritium gas exposure on samples of Nordel ${ }^{\mathrm{TM}} 1440$ and Royalene ${ }^{\circledR} 580 \mathrm{H}$ and also the radiolytic gas production during exposure. Both graphite-filled samples and formulations without graphite filling are being tested. Results of approximately one week tritium exposures have been documented earlier [1]. This report documents sample exposures to tritium of about 3-4 months.

A great deal of interest has developed in recent years in the area of conducting polymers due to the high levels of conductivity that can be achieved, comparable to that of highly conductive metals such as copper. Also, the physical and chemical properties of a polymer are retained and can be exploited for various applications, including light emitting diodes, anti-static packaging, electronic coatings, and sensors [2]. Polyaniline (PANi) is of particular interest in that there are previous studies of the mechanism for adjusting the level of conductivity of the conjugated polymer. PANi has unique properties in that the conductivity can be controlled via oxidation state of the main backbone chain, or by protonation of the imine groups.

Previous work has shown that the conductivity of PANi can change by five orders of magnitude when introduced to an ionizing radiation environment. Different studies report a measurable increase or decrease in conductivity with radiation exposure, depending on the presence of a dopant. It has been reported that the main mechanism for this change involves polymer main chain oxidation, or the creation of defects along the backbone. Due to this observed change of conductivity when exposed to ionizing radiation, it is proposed that PANi could serve as a remote sensor for tritium gas. One resistor in a Wheatstone bridge or similar circuit would employ PANi, and the circuit would alarm if this resistance changed due to tritium exposure. 
The circuit could be designed and calibrated to remotely signal an alarm after a designated time period of tritium exposure.

The advantages of using a polymeric sensor of this type rather than those currently in use are the flexibility of sensor geometry and relatively low cost. It is anticipated that these sensors can be made small enough for glovebox applications or have the ability to monitor the air tritium levels in places where a traditional monitor cannot be placed.

\section{EPDM EXPOSURE PROGRAM}

Sheets of Nordel ${ }^{\mathrm{TM}} 1440$ and Royalene ${ }^{\circledR} 580 \mathrm{H}$ were obtained from Los Alamos National Laboratory. Both standard graphite filled sheets and formulations synthesized without graphite at LANL were provided- the crosslink density of the formulations was the same. The filled Nordel ${ }^{\mathrm{TM}}$ had a nominal thickness of $1.94 \mathrm{~mm}$, the filled Royalene ${ }^{\circledR} 5800.85 \mathrm{~mm}$, the unfilled Nordel ${ }^{\mathrm{TM}} 0.7 \mathrm{~mm}$ and the unfilled Royalene ${ }^{\circledR} 0.65 \mathrm{~mm}$. The filled polymers appeared black, and the unfilled versions appeared light grey. Rectangular slab-shaped samples having nominal lengths of $33 \mathrm{~mm}$ and nominal width of $9 \mathrm{~mm}$ were cut from the sheets. The samples were weighed and their dimensions measured before exposure.

Exposure containers were designed per ASME B31.3 and per Savannah River Site (SRS) Tritium Facility requirements. The design limits are maximum temperature of $500^{\circ} \mathrm{F}$ and maximum pressure of $500 \mathrm{psig}$. The containers (Fig. 1) are 3/4" by 0.049 tubing, about 8" long, connected first to an adapter and then to a series of two bellows valves (Swagelok H-series). All wetted materials of the containers are Type 316 or Type 316L stainless steel.

Spacers were cut from $0.125 \mathrm{~mm}$ thick Type 316 stainless steel sheet. For the exposures discussed in this report, the spacers were cut to be rectangles longer than the sample length $(50 \mathrm{~mm})$ and about the same width as the sample $(9 \mathrm{~mm})$. The spacers were bent around the two ends of each sample to prevent the samples from contacting one other and the exposure container. Except for incidental contact with the spacers, the samples were not intentionally pressed or loaded during exposure.

Each exposure consisted of placing six samples of the same formulation in their spacers in one exposure container. The exposure containers were then attached to an experimental tritium gas system at the Savannah River Site Tritium Facilities. The containers were evacuated overnight, and back-filled with $100 \%$ tritium gas to about atmospheric pressure. The samples were exposed to tritium at the temperature inside the tritium system glovebox for between 108 and 129 days. The exposure temperature varied between 26 and $29^{\circ} \mathrm{C}$.

At the end of exposure, the pressure in the closed containers was measured on a pressure transducer by expanding the container gas into known system volumes. A grab sample of gas was then taken for mass spectroscopy analysis of the gas composition. The containers were then evacuated for several days. The container was then backfilled with argon to about 1 atmosphere and both valves were then closed. The container and samples were then moved from the tritium system to another building to characterize the samples by measuring mass and dimensions, visually inspecting the samples, and performing the bend test and Dynamic Mechanical Analysis (DMA).

\section{EPDM CHARACTERIZATION METHODS AND RESULTS}

\section{Density}

Irradiation damage of polymers can cause density changes that vary with the irradiation dose [3]. The density was found by measuring the mass and volume of each sample, both before and after tritium exposure. The density was calculated by dividing the total mass by the total volume of the samples in each container. 
The electronic scale used to measure sample masses before exposure read to $0.0001 \mathrm{~g}$, and that used after exposure (in the tritium facility) read to $0.001 \mathrm{~g}$. The volume of each sample was measured by multiplying the length, width, and thickness of the rectangular slab samples- the length and width were measured using a ruler with gradations to $0.5 \mathrm{~mm}$ and the thickness measured by a caliper reading to $0.01 \mathrm{~mm}$.

The density of each polymer was calculated by dividing the total mass (sum of sample masses) by the total volume (sum of sample volumes) of each set of samples (Table I). The only significant density change was of the filled Royalene ${ }^{\circledR}$. The one week exposure reported earlier resulted in no significant density change [1].

\begin{tabular}{|l|c|c|c|c|} 
Material & $\begin{array}{c}\text { Days } \\
\text { Exposure }\end{array}$ & Before & $\begin{array}{c}\text { Density } \\
\text { After } \\
\text { Exposure }\end{array}$ & \% Change \\
\hline Filled Nordel ${ }^{\mathrm{TM}}$ & 108 & 1.20 & 1.15 & $-4 \%$ \\
\hline $\begin{array}{l}\text { Filled } \\
\text { Royalene } \circledR\end{array}$ & 123 & 1.17 & 1.31 & $12 \%$ \\
\hline $\begin{array}{l}\text { Unfilled } \\
\text { Nordel }\end{array}$ & 126 & 0.97 & 0.94 & $-2 \%$ \\
\hline $\begin{array}{l}\text { Unfilled } \\
\text { Royalene }\end{array}$ & 122 & 0.98 & 0.94 & $-4 \%$ \\
\hline
\end{tabular}

Table I. Density of Four EPDM Formulations Studied, before and after tritium exposure, along with the relative density change.

The density change of the Filled Royalene ${ }^{\circledR}$ samples was caused by a $10 \%$ decrease in volume- the volumes of the other three materials increased by about 3\%. The mass of all the materials remained the same to $+/-$ $1 \%$. The gas composition of the Filled Royalene ${ }^{\circ}$ container included 23\% nitrogen (below) (presumably reflecting a leak into the system from the nitrogen gas glovebox). It is uncertain whether this caused the volume decrease observed only for Filled Royalene.

\section{Visual Appearance}

The filled samples had the same deep black color after exposure as before. The unfilled samples were slightly discolored, especially where the sample was away from its spacer (Fig. 2). The degree of discoloration varied- the sample pictured in Figure 2 was the most discolored. The effect of the spacer in reducing the discoloration was unexpected. The container gas certainly accessed the polymer surface as much from the side having the spacer as from the other side. Perhaps the metallic spacer preferentially absorbed decay particles. None of the spacers had the slightest discoloration or any evidence of EPDM degradation product on them.

\section{Bend Test for Sample Flexibility}

A small bench top vice (Fig. 3) was altered to facilitate performing bend tests per ASTM E 290 - 97a "Standard Test Methods for Bend Testing of Materials for Ductility". The test performed was a SemiGuided test for thin material, Arrangement B. Three of the six samples for each material were tested.

No loss of ductility was found for any of the filled EPDM samples by bend testing. Handling of the unfilled samples after exposure revealed changes in the strength of the samples. During handling, two of the unfilled Nordel $^{\mathrm{TM}}$ samples were damaged- one tore part-way through the width, and the other broke. The bend test 
resulted in "no break" on three samples- the torn sample and broken sample were bend tested, so that three whole samples remained for dynamic mechanical analysis (DMA). Three unfilled Royalene ${ }^{\circledR}$ samples were bend tested one day, and all revealed no break. The next day, when preparing a sample (not bend tested) for DMA, the sample broke. This sample was bend tested, and during a second bend this sample broke (Fig. 4). These observations indicate that tritium gas exposure degrades the properties of unfilled polymers exposed to the same conditions faster than filled polymers.

\section{Exposure Gas Pressure}

There was a significant total pressure increase in all containers (Table II). This type of pressure increase has been observed when other polymers are exposed to tritium in closed containers [4] and is a result of radiolytic production of gas by tritium beta decay and absorption of the beta kinetic energy by the polymer. Planned exposures for this program are for one year, and if the pressure increase rate remains the same, there is no issue with the containers being able to contain the gas (Table III). Interestingly, when the pressure increase rate is normalized by the sample volume in the container, the pressure increase rate for the unfilled formulations is about 2.7 times that of the filled formulations (Table IV). The inert filler occupies part of the sample volume and does not contribute significantly to the radiolytic production of gas. The filler also probably aids in dissipating the decay energy without forming gas molecules.

\begin{tabular}{|l|c|c|c|} 
Polymer & $\begin{array}{c}\text { Calculated } \\
\text { Exposure } \\
\text { time (d) }\end{array}$ & $\begin{array}{c}\text { Pressure in } \\
\text { Container After } \\
\text { Exposure (psia) }\end{array}$ & $\begin{array}{c}\text { Pressure } \\
\text { increase } \\
\text { during } \\
\text { exposure }\end{array}$ \\
\hline Filled Nordel ${ }^{\mathrm{TM}}$ & 108 & 18.74 & $28 \%$ \\
\hline Filled Royalene ${ }^{\circledR}$ & 123 & 16.23 & $11 \%$ \\
\hline Unfilled Nordel $^{\mathrm{TM}}$ & 122 & 20.51 & $40 \%$ \\
\hline Unfilled Royalene $^{\circledR}$ & 129 & 20.14 & $38 \%$ \\
\hline
\end{tabular}

Table II. Total Pressure in Containers at End of Exposure, and percent increase. Exposure time in days. Initial pressure 14.6 psia nominal in all cases. 


\begin{tabular}{|c|c|c|c|}
\hline Polymer & $\begin{array}{l}\text { Pressure } \\
\text { Increase/year } \\
\text { (psi/y) }\end{array}$ & $\begin{array}{c}\text { Expected } \\
\text { Pressure after } 1 \\
\text { year exposure } \\
\text { (psia) }\end{array}$ & $\begin{array}{c}\text { Expected } \\
\text { Time to reach } \\
500 \text { psi } \\
\text { pressure (y) }\end{array}$ \\
\hline Filled Nordel ${ }^{\mathrm{TM}}$ & 13.89 & 28.52 & 34.94 \\
\hline Filled Royalene $®$ & 4.76 & 19.39 & 101.94 \\
\hline Unfilled Nordel ${ }^{\mathrm{TM}}$ & 17.57 & 32.21 & 27.62 \\
\hline Unfilled Royalene $®$ & 15.57 & 30.21 & 31.18 \\
\hline
\end{tabular}

Table III. Predicted pressure increase rate, expected pressure after one year (based on increase rate), and time to reach $500 \mathrm{psi}$ (MAWP of container). (Decrease in pressure increase rate due to reduced tritium over time NOT accounted for here.)

\begin{tabular}{|l|c|c|} 
Polymer & $\begin{array}{c}\text { Volume of } \\
\text { Samples in } \\
\text { Container (cc) }\end{array}$ & $\begin{array}{c}\text { Pressure increase } \\
\text { rate per unit } \\
\text { volume (psi/y/cc) }\end{array}$ \\
\hline Filled Nordel $\mathrm{T}^{\mathrm{TM}}$ & 3.65 & 3.8 \\
\hline Filled Royalene ${ }^{\circledR}$ & 1.19 & 4.0 \\
\hline Unfilled Nordel & 1.66 & 10.6 \\
\hline Unfilled Royalene ${ }^{\circledR}$ & 1.52 & 10.2 \\
\hline
\end{tabular}

Table IV. Pressure increase rate per unit sample volume in container. Note the unfilled formulations pressure increase rate per unit volume is about 2.6 times greater than the filled formulations.

\section{Exposure Gas Composition}

The composition of the gas in the container changed dramatically (Fig. 5, Table V). All four containers were filled with nearly $100 \% \mathrm{~T}_{2}$ at the beginning, and the gas composition became roughly $20 \% \mathrm{H}_{2}, 45 \% \mathrm{HT}$, and only $30 \%$ remained $\mathrm{T}_{2}$ (Table $\mathrm{V}$ ). The filled Royalene ${ }^{\circledR}$ container had about $23 \%$ of $\mathrm{M} / \mathrm{C} 28$ which is either nitrogen or carbon monoxide. This is believed to have resulted from an unknown inadvertent in-leakage of nitrogen from the glovebox. Each container had a different set of minor species- no pattern in the lower concentration molecule types was noted.

\begin{tabular}{|l|c|c|c|c|c|c|}
\multicolumn{2}{|c|}{} & \multicolumn{5}{|c|}{ Mole Percent of Species After Exposure } \\
Polymer & $\begin{array}{c}\text { Exposure } \\
\text { Time (d) }\end{array}$ & $\mathbf{H}_{\mathbf{2}}$ & $\mathbf{H T}$ & $\mathbf{T}_{\mathbf{2}}$ & ${ }^{3} \mathbf{H e}$ & $\mathbf{N}_{\mathbf{2}}$ \\
\hline Filled Nordel & 108 & 24.236 & 43.527 & 25.039 & 2.841 & 1.022 \\
\hline $\begin{array}{l}\text { Filled } \\
\text { Royalene }\end{array}$ & 123 & 10.836 & 30.352 & 29.468 & 2.731 & 22.758 \\
\hline $\begin{array}{l}\text { Unfilled } \\
\text { Nordel }\end{array}$ & 122 & 21.762 & 44.111 & 28.190 & 2.936 & 0.063 \\
\hline $\begin{array}{l}\text { Unfilled } \\
\text { Royalene }\end{array}$ & 129 & 21.877 & 44.134 & 28.765 & 3.186 & 0.068 \\
\hline
\end{tabular}

Table V. Composition of major gas species in containers after exposure

During the exposure time about $3 \%{ }^{3} \mathrm{He}$ was formed in all containers. The published decay factor for tritium is $0.99984601 /$ day [5], meaning that multiplying this constant by the time in days results in the fraction of tritium remaining (not decayed). Since in the aggregate two helium-3 atoms are created from one tritium 
molecule, the creation factor for ${ }^{3} \mathrm{He}$ is $2 *(1-0.99986401) /$ day or 0.00030798 , so the expected ${ }^{3} \mathrm{He}$ concentration is between $3.3 \%$ (108 days) and 4.0\% (129 days). ${ }^{3} \mathrm{He}$ should not be trapped within the polymer, and is likely mobile enough to permeate out of the polymer.

\section{Dynamic Mechanical Analysis- Testing Details}

Dynamic mechanical analysis measures the elastic and viscoelastic parameters related to small cyclic deformation of materials- storage modulus, loss modulus, and tan delta. The storage modulus is the constant relating the amount of elastic deformation to a given applied load. For sealing applications, the storage modulus must not be too high- the O-ring seals by deforming and contacting intimately with the metallic sealing surfaces. The loss modulus is a measure of the time-dependent deformation under a given load, and provides insight to the amount of molecular motion occurring at various temperatures. Tan delta is the ratio of the loss modulus to the storage modulus.

A TA Instruments Model 2980 dynamic mechanical analyzer were used for this study. This is a forced oscillation, controlled (non-resonant), constant amplitude instrument. The single-cantilever-beam clamp, or sample holder, was used, being the clamp of choice for measuring the glass transition temperature of elastomers. The oscillation amplitude was chosen to be 40 microns for exposed samples. An "amplitude sweep" at several temperatures revealed a wide range of oscillation amplitude results in equivalent DMA parameter measurements [1].

DMA data was taken using the DMA Multi-Frequency mode, at frequencies of 1, 3, and $10 \mathrm{~Hz}$. The DMA continuously acquired data at each of the set frequencies in sequence during the increasing temperature scans. The sampling rate was set at $3.0 \mathrm{sec} /$ point, which specifies the time over which data is acquired for each set frequency.

Each DMA test involved stabilizing the temperature at $-70^{\circ} \mathrm{C}$., remaining at this temperature for 10 minutes to further establish isothermal conditions around the sample, and then increasing the sample temperature at $1^{\circ} \mathrm{C}$. per minute until $0^{\circ} \mathrm{C}$. The TA 2980 has both electrical resistance heating and cooling by evaporated cold nitrogen gas from a liquid nitrogen container called the Gas Cooling Accessory (GCA) which is a part of the DMA system. The control software enables optimized control of cooling and heating for a given temperature and heating rate. The system was regularly calibrated at least once a month.

\section{Dynamic Mechanical Analysis- Results}

A typical plot of storage modulus, loss modulus, and tan delta for filled Nordel ${ }^{\mathrm{TM}}$ after 108 days tritium exposure with temperature reveals drastic effect of temperature on these properties, and the frequency dependence of the properties (Figs. 6,7). The storage modulus is high at low temperature (below the glass transition, below), and decreases dramatically with temperature. The loss modulus and tan delta rise to a maximum and then decline with temperature slightly above the glass transition (see below). At a given temperature, the storage modulus is higher for the higher frequency- the polymer is "stiffer" at higher frequencies. The peak temperature in both cases increases with increasing frequency.

The glass transition temperature $\left(\mathrm{T}_{\mathrm{g}}\right)$ is a critical parameter of amorphous polymers and elastomers, particularly for low-temperature applications. The $\mathrm{T}_{\mathrm{g}}$ value represents the molecular transition between rubbery and "glassy" behavior. $T_{g}$ is important in sealing applications because elastomers lack the resiliency at temperatures significantly below $\mathrm{T}_{\mathrm{g}}$ that allows them to form a good mechanical seal. Elastomers may be useful for $10-15^{\circ} \mathrm{C}$. below the $\mathrm{T}_{\mathrm{g}}$ value, but this depends strongly on the specific seal design.

$\mathrm{T}_{\mathrm{g}}$ can be determined by several methods, including differential scanning calorimetry (DSC), dilatometry, and DMA. There are at least two accepted methods for determining $\mathrm{T}_{\mathrm{g}}$ from DMA data. ASTM E 1640 
"Standard Test Method for Assignment of the Glass Transition Temperature by Dynamic Mechanical Analysis" uses the intersection of two tangents of the storage modulus versus temperature curve: the tangent of data below $\mathrm{T}_{\mathrm{g}}$ and the tangent at the inflection point of the sigmoidally changing storage modulus with temperature in the middle of the glass transition. The temperature of the tangents intersection is regarded as being $T_{\mathrm{g}}$. In this case, the standard requires an applied frequency of $1 \mathrm{~Hz}$ and a temperature increase rate of $1^{\circ} \mathrm{C}$ /minute, which were used in these tests. Either the linear or logarithmic plots can be used for this construction. In this work, the linear plot is used by the analysis software (provided by the DMA manufacturer, TA Instruments). The other accepted method is the peak temperature of the loss modulus [6]. Both methods are illustrated for the data in Fig. 9, and the $\mathrm{T}_{\mathrm{g}}$ determined both ways for samples exposed to tritium for between 108 and 129 days is presented in Table VI.

Along with the $\mathrm{T}_{\mathrm{g}}$ data presented previously [1], the glass transition temperature of all the tested EPDM formulations increases with tritium exposure (Fig. 9). The glass transition increased by about $3^{\circ} \mathrm{C}$ during the four-month exposure. This increase caused by tritium exposure was the same for all the formulations. The Nordel ${ }^{\mathrm{TM}}$ formulations had a $\mathrm{T}_{\mathrm{g}}$ about $3^{\circ} \mathrm{C}$ higher than the Royalene ${ }^{\circledR}$ formulations, and there was no effect of whether the elastomer was filled or not.

\begin{tabular}{|c|c|c|c|}
\hline \multirow[b]{2}{*}{ Material } & \multirow[b]{2}{*}{$\frac{\text { Exposure }}{\text { Time }}$} & \multicolumn{2}{|c|}{$\mathrm{T}_{\mathrm{g}}\left({ }^{\circ} \mathrm{C}.\right)$} \\
\hline & & $\frac{\text { ASTM E } 1640}{\text { (Storage modulus }}$ & $\frac{\text { Loss Modulus }}{\text { Peak }}$ \\
\hline Nordel $^{\mathrm{TM}}$ (filled) & 108 & -48 & -40 \\
\hline Nordel $^{\mathrm{TM}}$ (filled) & 108 & -48 & -41 \\
\hline Nordel $^{\mathrm{TM}}$ (filled) & 108 & -49 & -41 \\
\hline Royalene® (filled) & 123 & -52 & -44 \\
\hline Royalene $®$ (filled) & 123 & -52 & -44 \\
\hline Royalene $®$ (filled) & 123 & -51 & -44 \\
\hline Nordel $^{\mathrm{TM}}$ Unfilled & 126 & -48 & -40 \\
\hline Nordel $^{\mathrm{TM}}$ Unfilled & 126 & -48 & -39 \\
\hline Nordel $^{\mathrm{TM}}$ Unfilled & 126 & -47 & -40 \\
\hline Royalene $®$ Unfilled & 122 & -52 & -44 \\
\hline Royalene $®$ Unfilled & 122 & -51 & -44 \\
\hline Royalene $®$ Unfilled & 122 & -52 & -44 \\
\hline
\end{tabular}

Table VI. Glass Transition Temperature calculated using ASTM E 1640 and using the peak temperature of the loss modulus for all samples undergoing DMA testing. $1 \mathrm{~Hz}$.

\section{INITIAL PANi IRRADIATION RESULTS}

Two types of polyaniline films were obtained commercially from Crosslink, USA. The films were fabricated by mechanically drawing down the PANi polymer in solution onto a thermoplastic PET substrate. The substrate was supplied for mechanical stability as the films were approximately $25 \mu \mathrm{m}$ thick. The dopants used in the formulations are proprietary and not known by SRNL at this time. In order to fully characterize the behavior of this material in an ionizing radiation environment, samples of the two grades of PANi film were initially exposed to either gamma irradiation (from a ${ }^{60} \mathrm{Co}$ source) or ultraviolet light. The samples were exposed in air and at ambient temperature. The surface conductivity measurements were made with a PRS812 surface resistivity meter with a small sample concentric ring probe. No electrodes were deposited onto the polymer surface to make these measurements. Ten surface conductivity measurements were taken for each sample and the highest and lowest values were not averaged. 
The results of the gamma exposures (Fig. 10) clearly show a reduction in surface conductivity of the PANi films irradiated at a constant dose rate until a total dose of $10^{7} \mathrm{rad}$ is reached. These results are expected, due to the formation of defects along the polymer chain (chain scission), which restrict movement of the electrons through the material. Interestingly, at higher total dose, the conductivity increases for both grades of PANi and then falls slightly at $10^{9} \mathrm{rad}$ total dose. The mechanism for this increase-then-decrease is yet to be determined and will be fully explored in FY '09. It is postulated that the chain scission mechanism dominates at total doses of less than $10^{7} \mathrm{rad}$ and an increase in cross-link density dominates at higher dose rates. An increase in cross-link density may occur when the free radicals formed during the initial irradiation begin to recombine. This recombination process would be taking place faster than the backbone chains are broken. The total doses chosen for gamma exposures have been shown to mimic those of short (days) to long term (months) tritium radiation exposure.

Visual inspection of the samples after gamma irradiation did not provide much proof of sample degradation. One grade of PANi was green in color and started to fade to clear at high total doses. However, the samples became much more fragile at high dose rates. After $10^{9}$ rad total dose, the samples would fall apart after brief handling for measurement.

The UV exposures after 5 and 12 days in a commercial UV lamp radiating at $168 \mathrm{~mW}$ at $10 \mathrm{~cm}$ distance from the source provided drastic reductions in surface conductivity by more than four orders of magnitude. This decrease is most likely due to oxidation (scission) of the polymer chains. There was no visual indication of radiation damage after UV irradiation.

\section{PANi Tritium Exposures}

The samples will be exposed to tritium gas in stainless steel exposure containers specifically designed for this purpose (see Figure 1). Each container has a volume of $55 \mathrm{cc}$, and 3 - 6 samples will be placed in each container, along with stainless steel spacers (if needed). The containers will then be attached to the experimental tritium gas system and loaded with either 760 Torr or 76 Torr of tritium. The polymer samples will be exposed to tritium for varying lengths of time, according to the schedule listed in Table VII. The containers can be detached from the system during exposure. After the determined exposure time, the total pressure and composition of the gas in the container will be characterized using the tritium system facilities. The tritium gas will be removed from the container, and the container will be transported to another building for conductivity measurements. A surface conductivity meter (Prostat, model PRS 812) with small sample concentric ring probes will be used to measure the surface conductivity of the polyaniline samples in a tritium hood and also in a nitrogen glovebox. The two different measurements should elucidate the effects of moisture on sample conductivity. Unexposed control samples will be characterized using the same procedures and facilities as exposed samples. The gas in the container after exposure is expected to be tritium, helium-3 from tritium decay, and protium (hydrogen) from radiolysis.

Currently, experiment numbers 9 and 10 have been loaded with 1 atm tritium- two samples of each grade of PANi in the exposure container and will be left for 1000 hours. The surface conductivity was measured of two control samples that have been stored contacting nitrogen gas in the tritium glovebox for several months. The results of these measurements are comparable to those measurements taken at 0 rad total dose shown in Figure 10. 


\begin{tabular}{|l|l|l|}
\hline $\begin{array}{l}\text { Experiment } \\
\text { number }\end{array}$ & $\begin{array}{l}\text { Exposure } \\
\text { Time (hour) }\end{array}$ & $\begin{array}{l}\text { Exposure Pressure } \\
\text { (torr) }\end{array}$ \\
\hline 1 & 0.1 & 76 \\
\hline 2 & 0.1 & 760 \\
\hline 3 & 1 & 76 \\
\hline 4 & 1 & 760 \\
\hline 5 & 10 & 76 \\
\hline 6 & 10 & 760 \\
\hline 7 & 100 & 76 \\
\hline 8 & 100 & 760 \\
\hline 9 & 1000 & 76 \\
\hline 10 & 1000 & 760 \\
\hline
\end{tabular}

Table VII. List of planned experiments with test number, exposure time, and exposure pressure.

\section{SUMMARY and CONCLUSIONS}

\section{$E P D M$}

Samples of filled and unfilled Nordel ${ }^{\mathrm{TM}} 1440$ and filled and unfilled Royalene ${ }^{\circledR}$ 580H EPDM elastomer were exposed to tritium gas initially at one atmosphere for between three and four months at ambient temperature. The following observations were made:

- $\quad$ The density of Filled Royalene ${ }^{\circledR}$ increased by $12 \%$, reflecting a volume decrease of $10 \%$ (possibly resulting from the Filled Royalene container having 23\% nitrogen after exposure); the volumes of the other three polymers increased by about 3\%, and the mass of all four EPDM formulations did not change;

- The originally grey unfilled samples discolored slightly, and the discoloration increased in locations not facing the stainless steel spacer used with each sample;

- Several of the unfilled samples broke while being handled, and bend testing revealed one break of an unfilled Royalene ${ }^{\circledR}$ sample; this observation may indicate that filled elastomers are more resistant to tritium exposure than unfilled versions (no filled samples broke);

- The gas pressure in the closed exposure containers significantly increased for all four materials, by radiolysis of the polymer by tritium decay; the pressure increase per unit volume of polymer sample was 2.7 times greater for the unfilled samples than their filled counterparts;

- The gas composition changed markedly from the initial pure tritium- the major species were $20 \% \mathrm{H}_{2}$, $45 \% \mathrm{HT}$, and only $30 \%$ remained $\mathrm{T}_{2}$; the ${ }^{3} \mathrm{He}$ production was somewhat lower than calculated;

- The glass transition temperature of all formulations increased about $3^{\circ} \mathrm{C}$. during the exposure; the $\mathrm{T}_{\mathrm{g}}$ of the Nordel $^{\mathrm{TM}}$ formulations was about $3^{\circ} \mathrm{C}$. higher than Royalene ${ }^{\circledR}$.

From these observations, it can be concluded that filled elastomers are more resistant to tritium degradation and produce less radiolytic gas, and there are significant isotope exchange reactions between tritium gas and EPDM elastomers.

\section{$P A N i$}

Two types of polyaniline (PANi) film were exposed to ${ }^{60} \mathrm{Co}$ gamma irradiation and ultraviolet light in air, and the surface conductivity was reduced by several orders of magnitude and two mechanisms for 
degradation were suggested. If PANi behaves similarly when exposed to tritium, PANi could well be a sensitive tritium sensor material. Currently, the 1000-hour exposure samples (experiment numbers 9 and 10) are being exposed to tritium.

\section{FUTURE WORK}

\section{$E P D M$}

Samples of filled and unfilled Nordel ${ }^{\mathrm{TM}} 1440$ and filled and unfilled Royalene ${ }^{\circledR} 580 \mathrm{H}$ EPDM elastomer are being exposed to tritium at ambient temperature and initially 1 atmosphere currently, and will be characterized (as in this report) after six-, and twelve months exposure times.

\section{$P A N i$}

The results of the tritium exposure tests shown in Table VII will be correlated to the gamma and UV exposure results to aid in the design of an optimal tritium sensor. Future work also includes the investigation of the mechanism of an increase in surface conductivity for gamma irradiation doses greater than $10^{7}$ rad. Exposures for gamma irradiation are planned in a deuterium environment as well as more UV exposures (in air) to closely capture the region that certain degradation mechanisms dominate. Additional grades of PANi polymer may be evaluated and a prototype tritium sensor system will be designed.

\section{REFERENCES}

1) E.A. Clark, "Effects of One Week Tritium Exposure on EPDM Elastomer". Report SRNL-STI-00524, Savannah River National Laboratory, Washington Savannah River Company, Aiken SC (7 June 2007).

2) W.M. de Azevedo, A.P. da Costa Lima, E.S. de Araujo, "Radiation-Induced Effects on Electrical Properties of Polyaniline. Radiation Protection Dosimetry. Vol 84 (1-4), 1999, 77-81.

3) "Radiation Chemistry of Polymeric Systems", A. Chapiro, Wiley- Interscience, New York (1962) p. 392.

4) E.A. Clark, K.L. Shanahan, "Effects of Tritium on UHMW-PE, PTFE, and Vespel® polyimide". Fusion Science and Technology, Vol. 52, Number 4, November 2007, pp. 1007-1011.

5) DOE Handbook: Tritium Handling and Safe Storage. US Department of Energy Handbook, Appendix A, DOE-HDBK 1129-2007 (2007). URL: http://www.hss.energy.gov/NuclearSafety/techstds/standard/hdbk1129/hdbk1129-07.pdf

6) "Mechanical Properties of Polymers and Composites", 2nd Ed., L.E. Nielsen, R.F. Landel, Marcel Dekker, Inc, New York (1994) p. 141.

\section{ACKNOWLEDGEMENTS}

It is a pleasure to acknowledge: Wanda Britt for sample characterization before testing, sample tracking and handling, mass and volume measurements, DMA operation, hood decontamination, waste management; Mike Thomas for DMA installation and facility interface; Kipp Neikirk for exposure container design and procurement; Greg Staack and Dante Pilgrim for tritium exposure and sample transport and Chris Beam for gamma irradiation. 


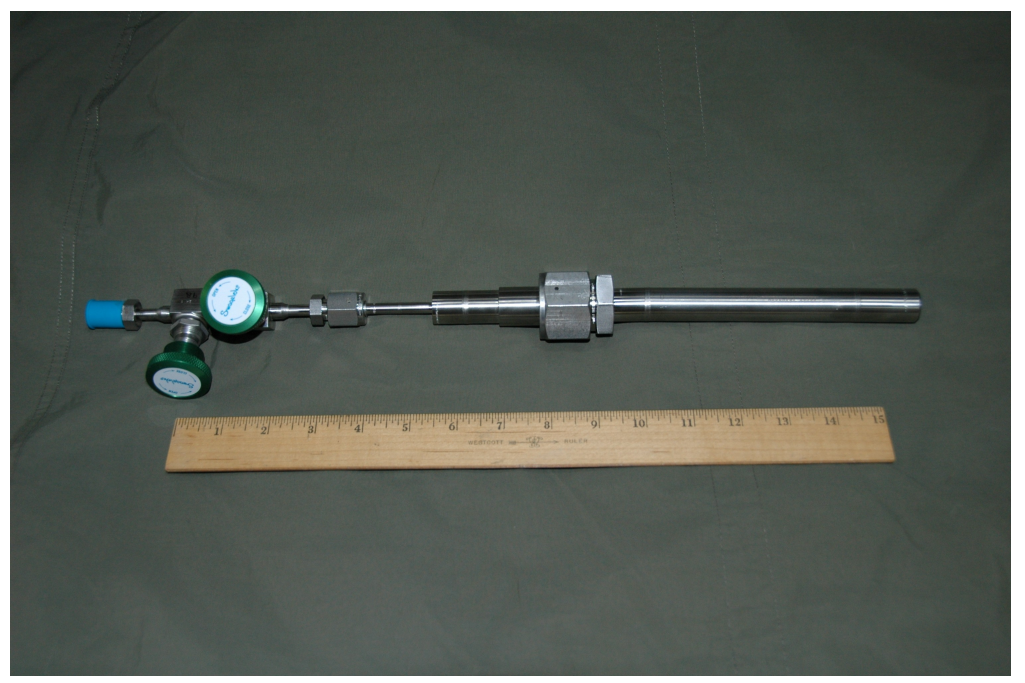

Figure 1.Photograph of Tritium Exposure Container.

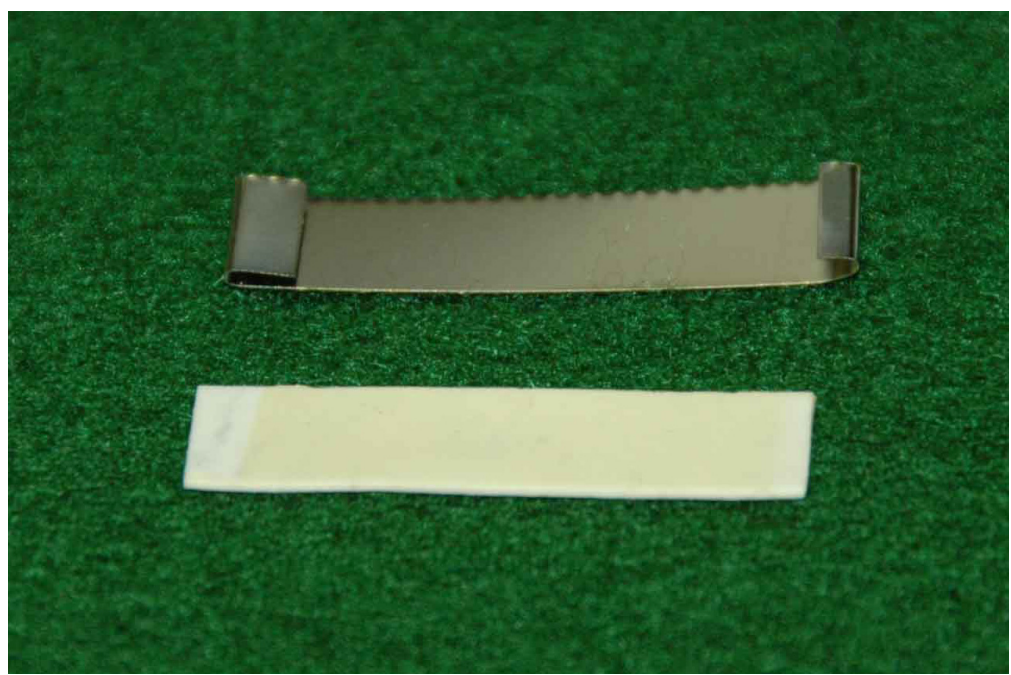

Figure 2. Photograph of Unfilled Nordel ${ }^{\mathrm{TM}}$ sample after tritium exposure. Note discoloration away from where spacer covered the sample. 


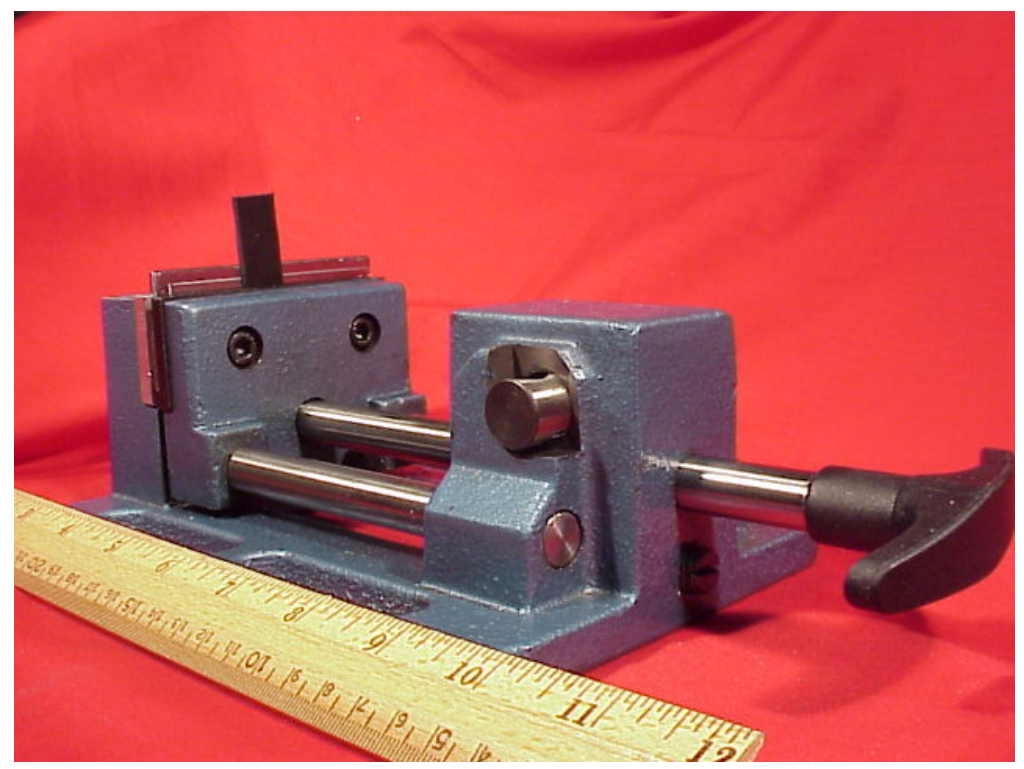

Figure 3. Photograph of Bend Tester, ASTM E 290 - 97a; Semi-Guided Bend, Thin Material. Note filled EPDM sample in position for bend.

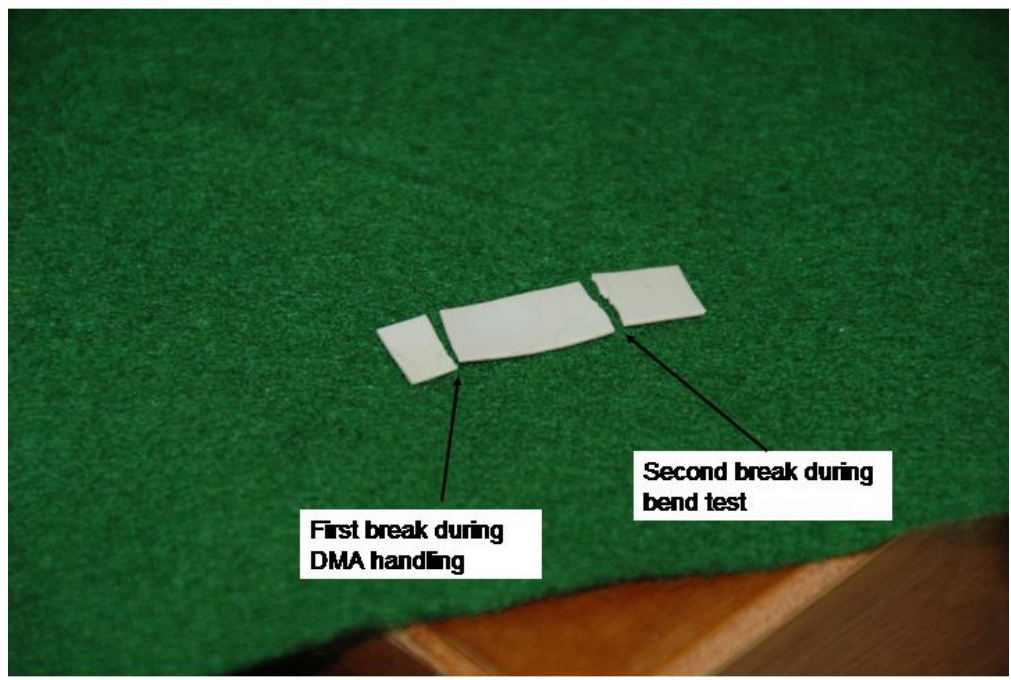

Figure 4. $\quad$ Photograph of unfilled Royalene ${ }^{\circledR}$ sample, with two breaks as indicated. 


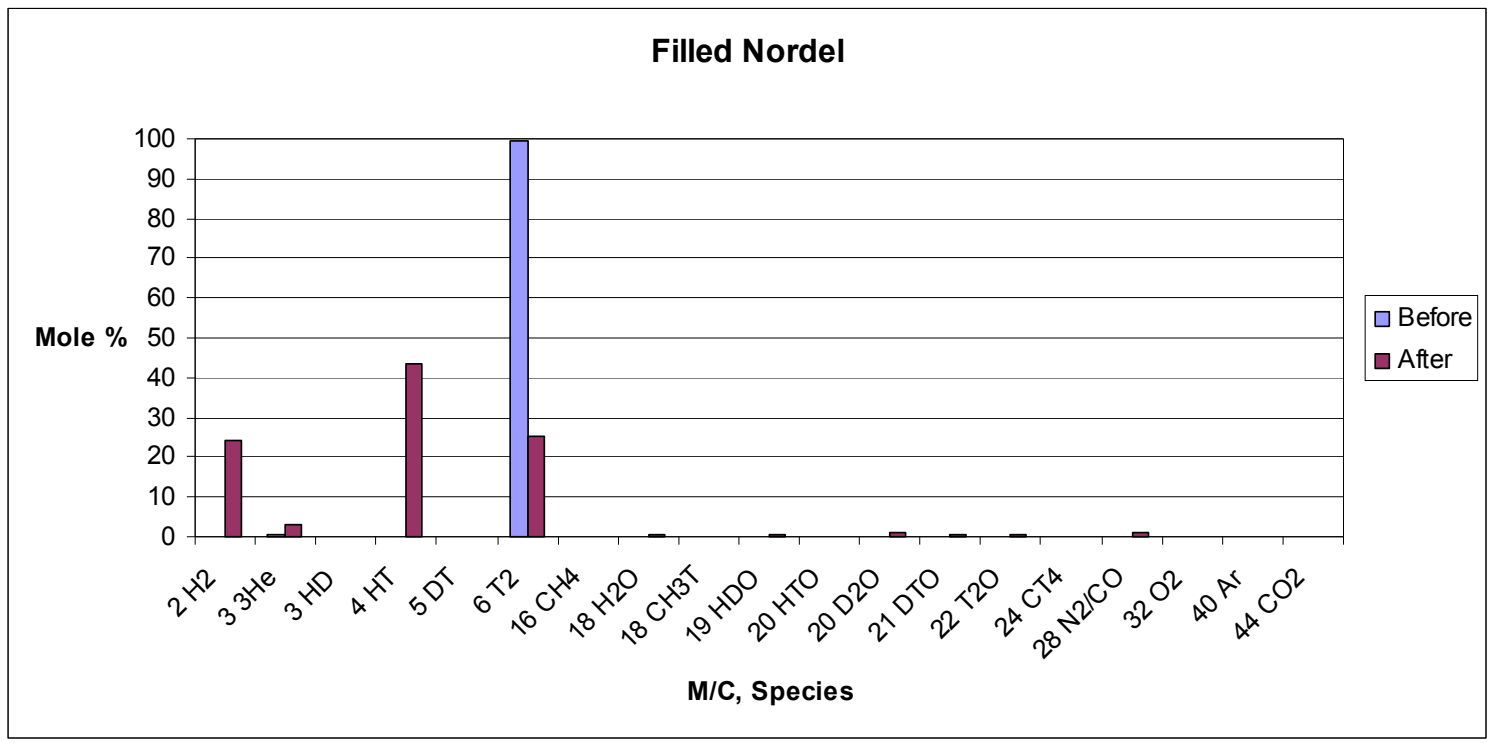

a.

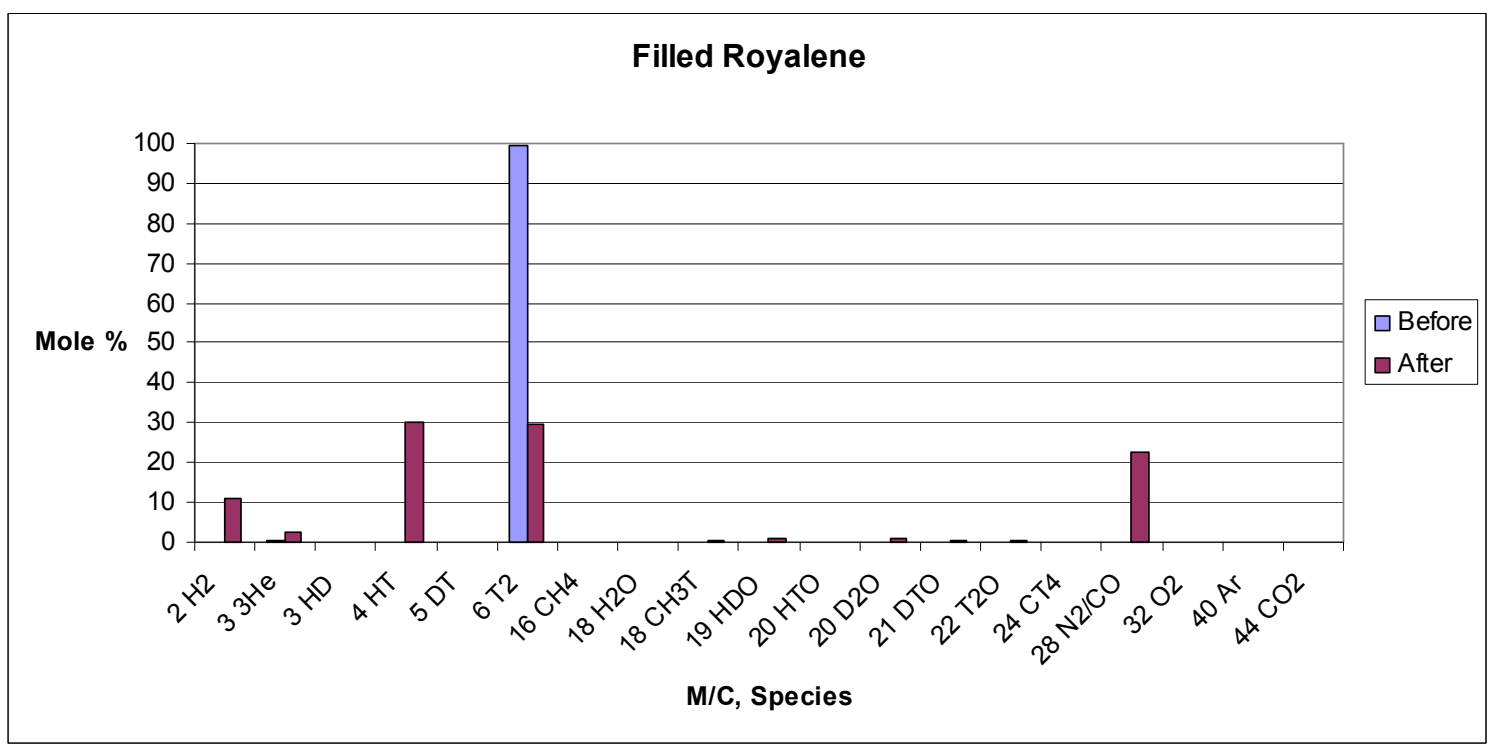

b.

Figure 5. Mole percent of species in gas- species shown by mass/charge ratio and formula. Before and after tritiuim exposure. a. filled $\operatorname{Nordel}^{\mathrm{TM}}$, b. filled Royalene ${ }^{\circledR}$ (continued next page) 


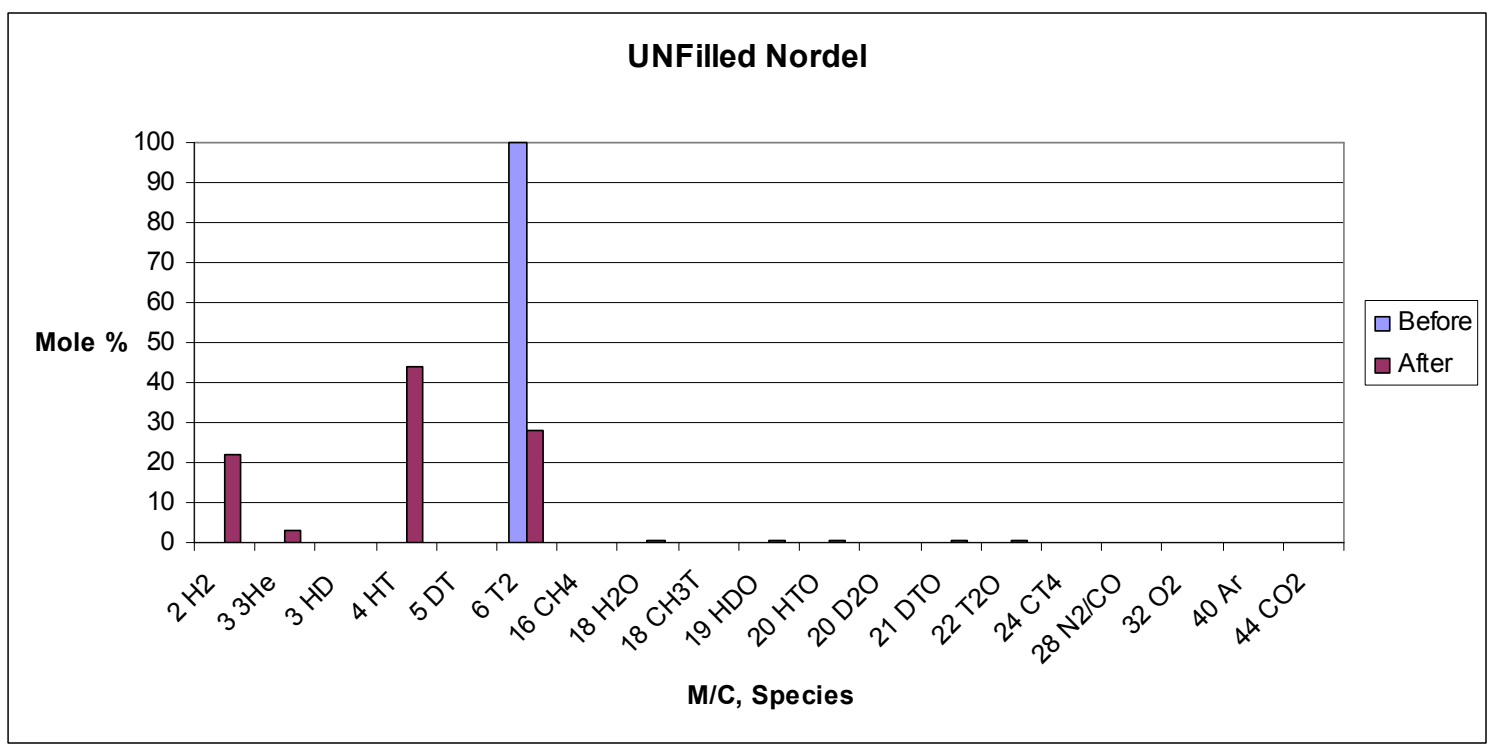

c.

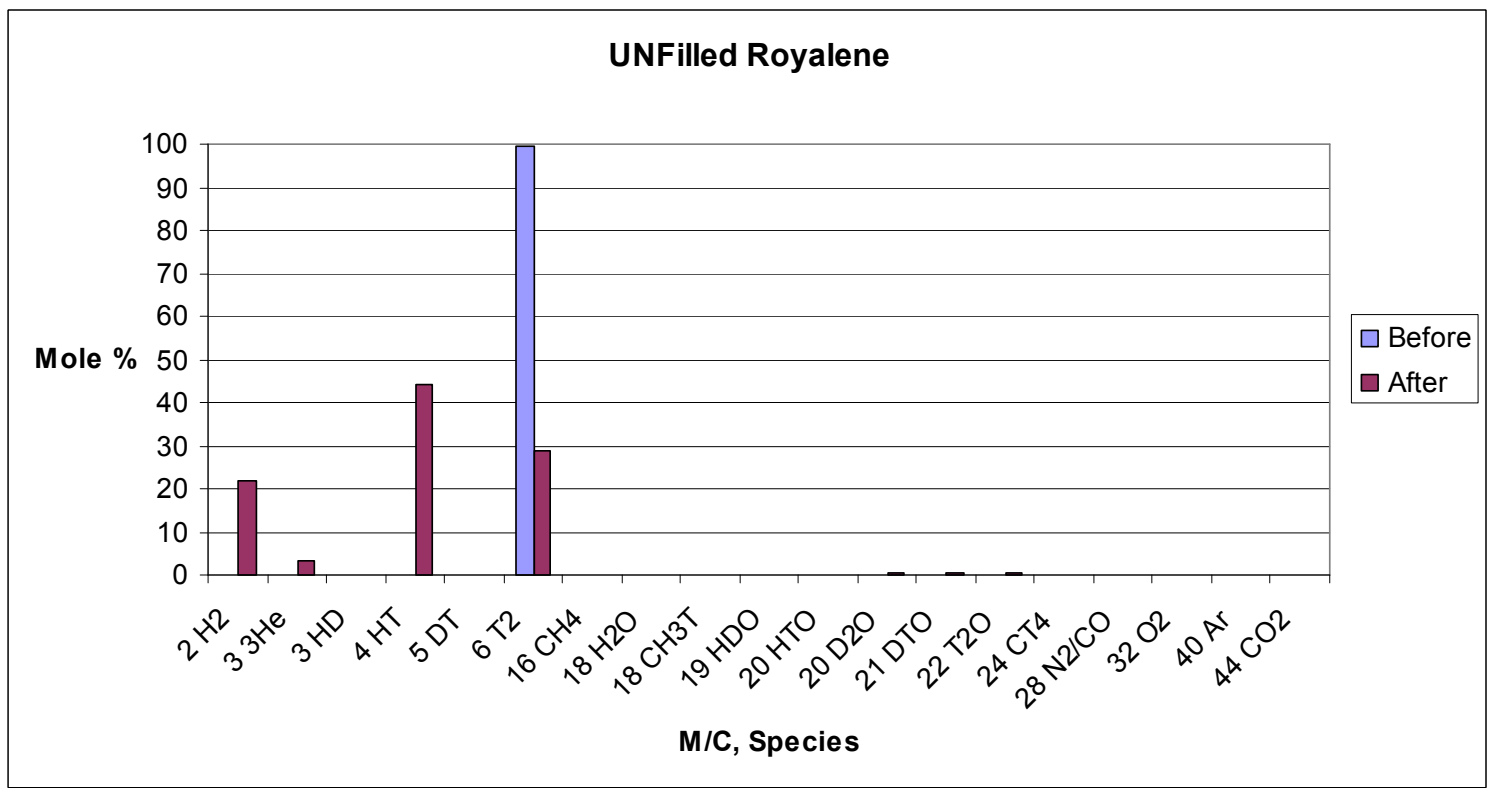

d.

Figure 5 (continued) Mole percent of species in gas- species shown by mass/charge ratio and formula. Before and after tritiuim exposure.c. Unfilled Nordel ${ }^{\mathrm{TM}}$, d. Unfilled Royalene ${ }^{\circledR}$. 


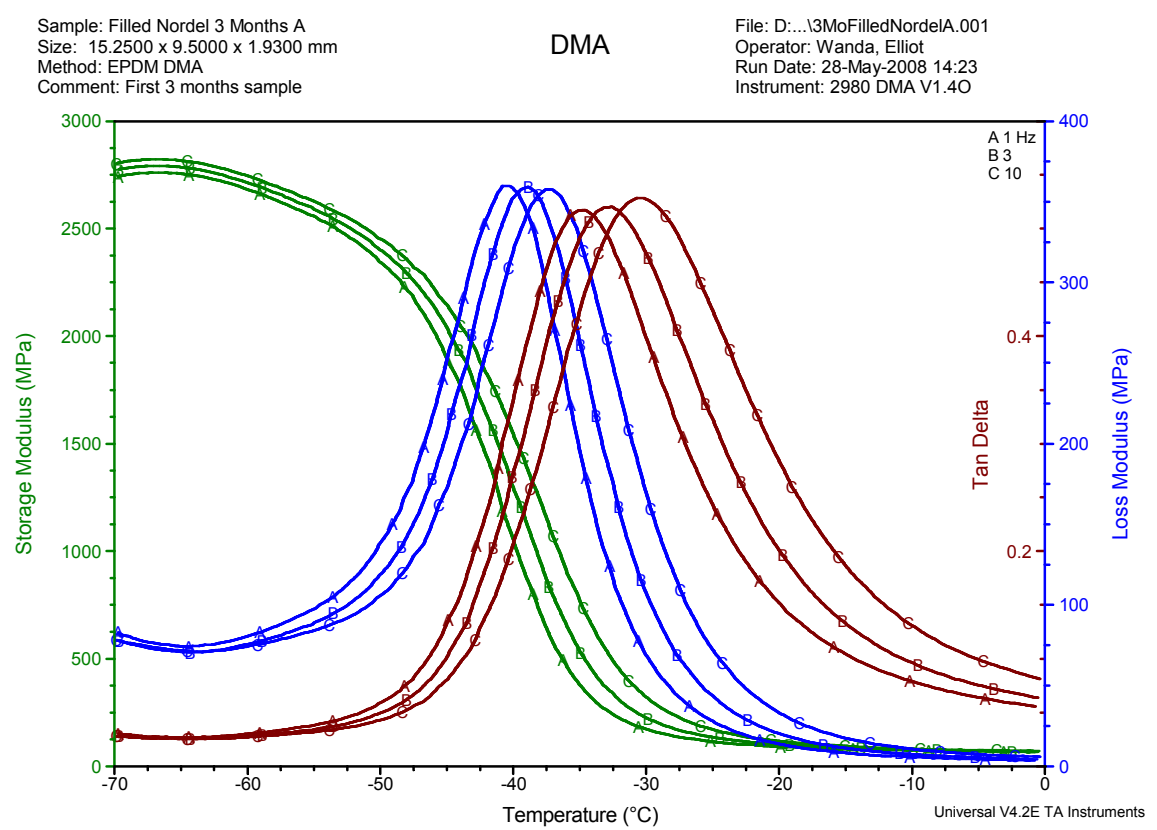

Figure 6. Storage modulus (green), loss modulus (blue), tan delta (brown) for filled Nordel ${ }^{\mathrm{TM}}$. Temperature increased at $1^{\circ} \mathrm{C}$. per minute, 40 microns oscillation amplitude. Letters denote test frequency $(1$, $3,10 \mathrm{~Hz}$ ) as given in legend. 108 days tritium exposure.

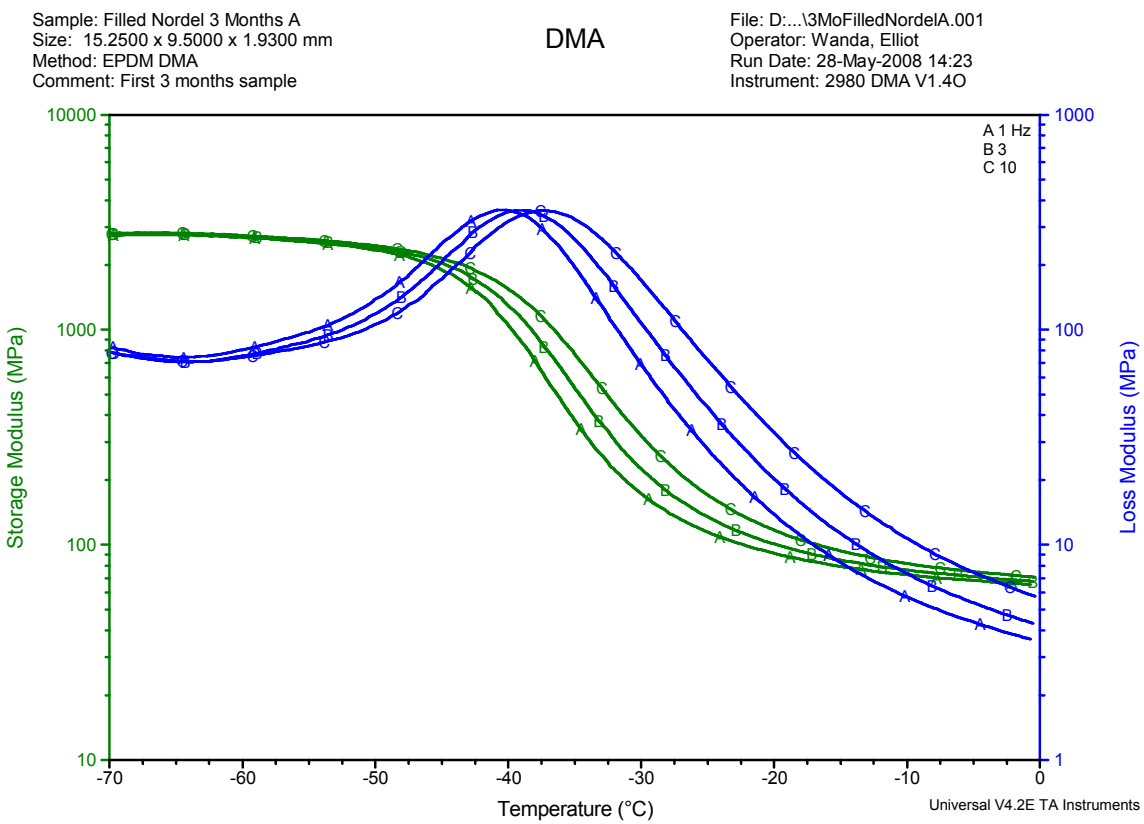

Figure 7. Logarithm of storage modulus (green), loss modulus (blue) for filled Nordel ${ }^{\mathrm{TM}}$ (same data as Fig. $6)$. 


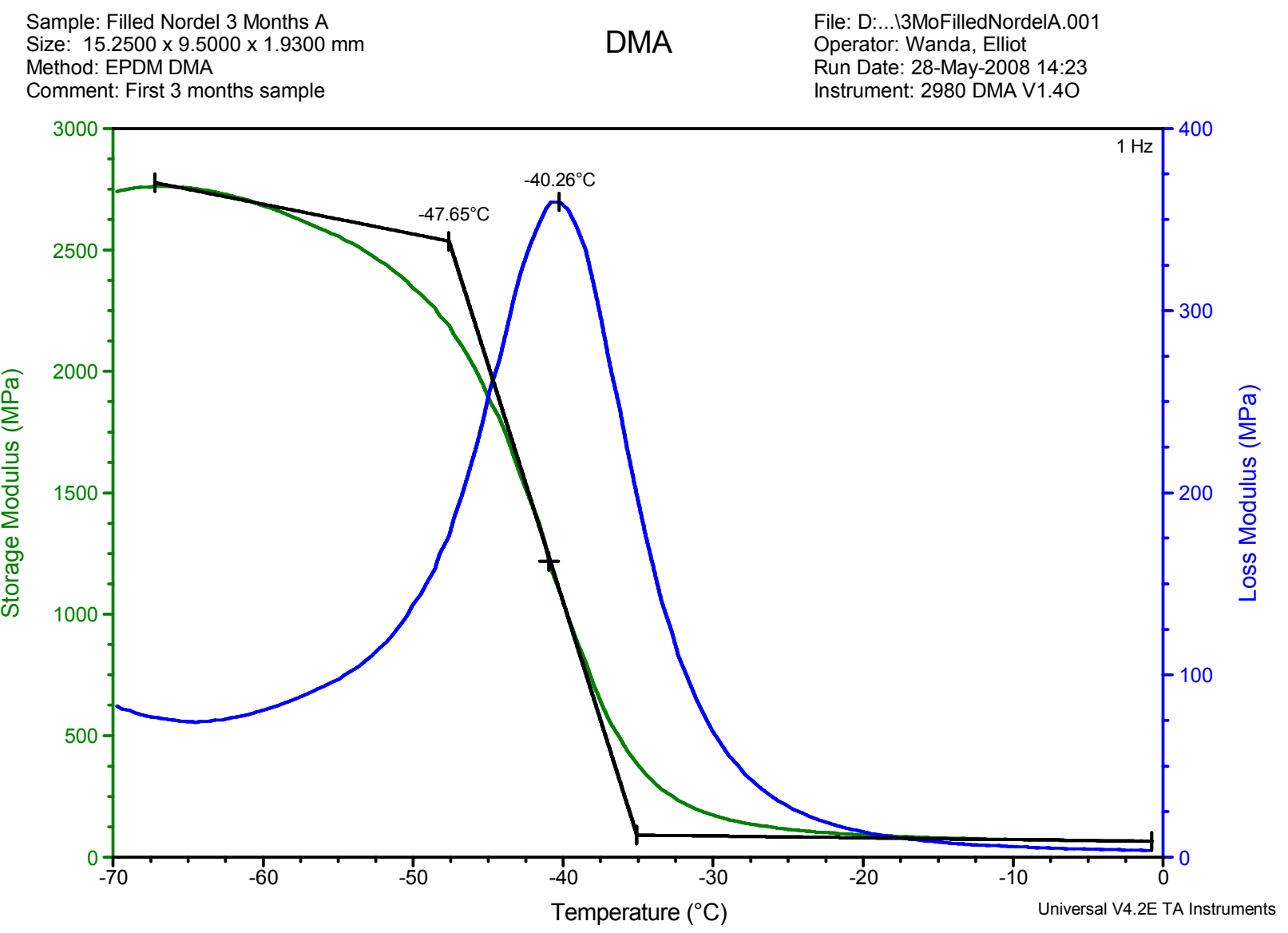

Figure 8. Storage modulus and loss modulus of filled Nordel ${ }^{\mathrm{TM}}$ with increasing temperature (data part of Figs. 7,8 ). ASTM E 1640 construction by DMA analysis software obtains $-47.7^{\circ} \mathrm{C}$. (tangent intersection), peak of loss modulus obtains $-40.3^{\circ} \mathrm{C} .1 \mathrm{~Hz}$ data, $1^{\circ} \mathrm{C} . /$ minute heating rate. 


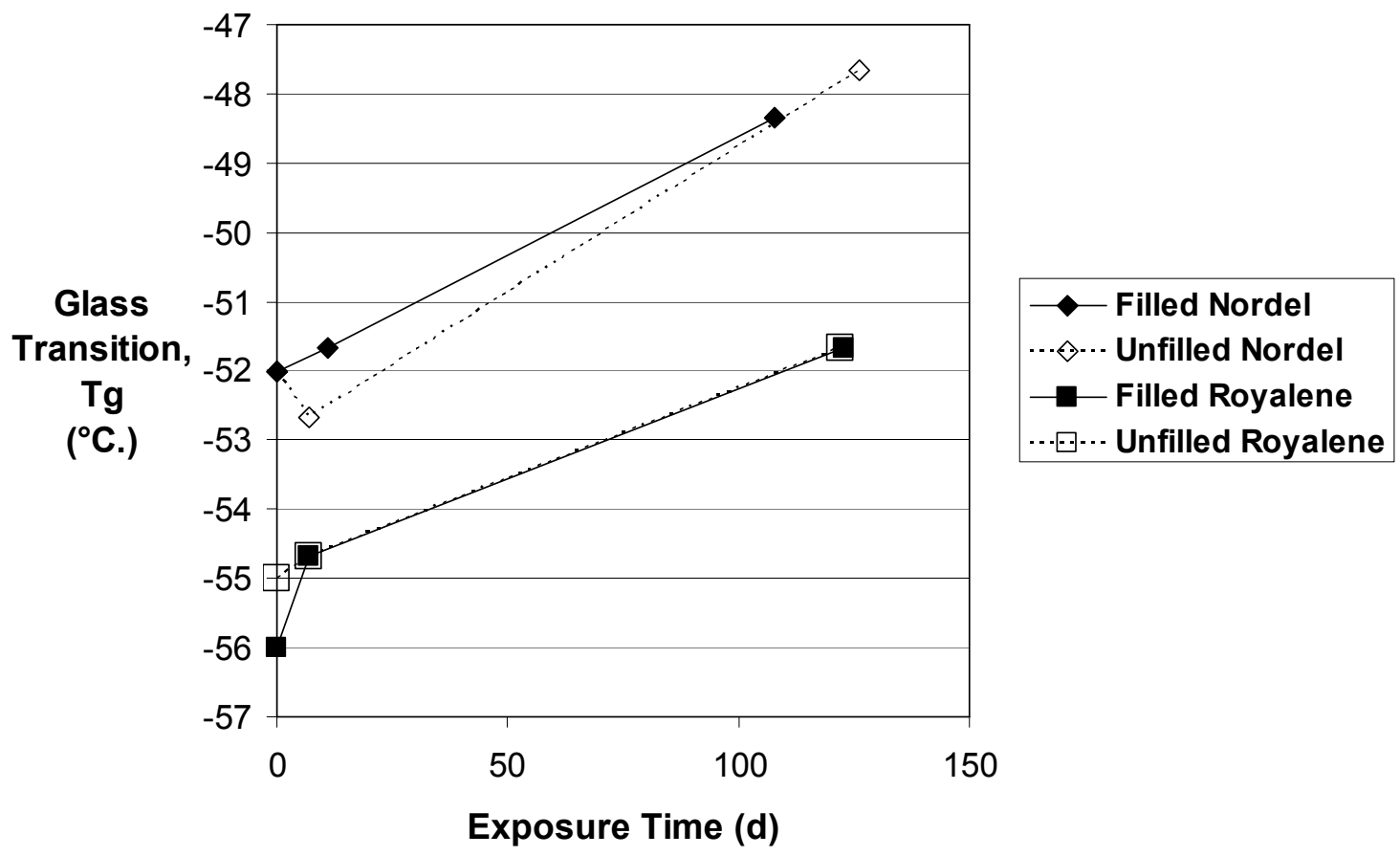

Figure 9. Glass transition temperature versus tritium exposure time. Formulations as noted. 
Reduction in Conductivity with Gamma Exposure of PANi Polymer (2 types)

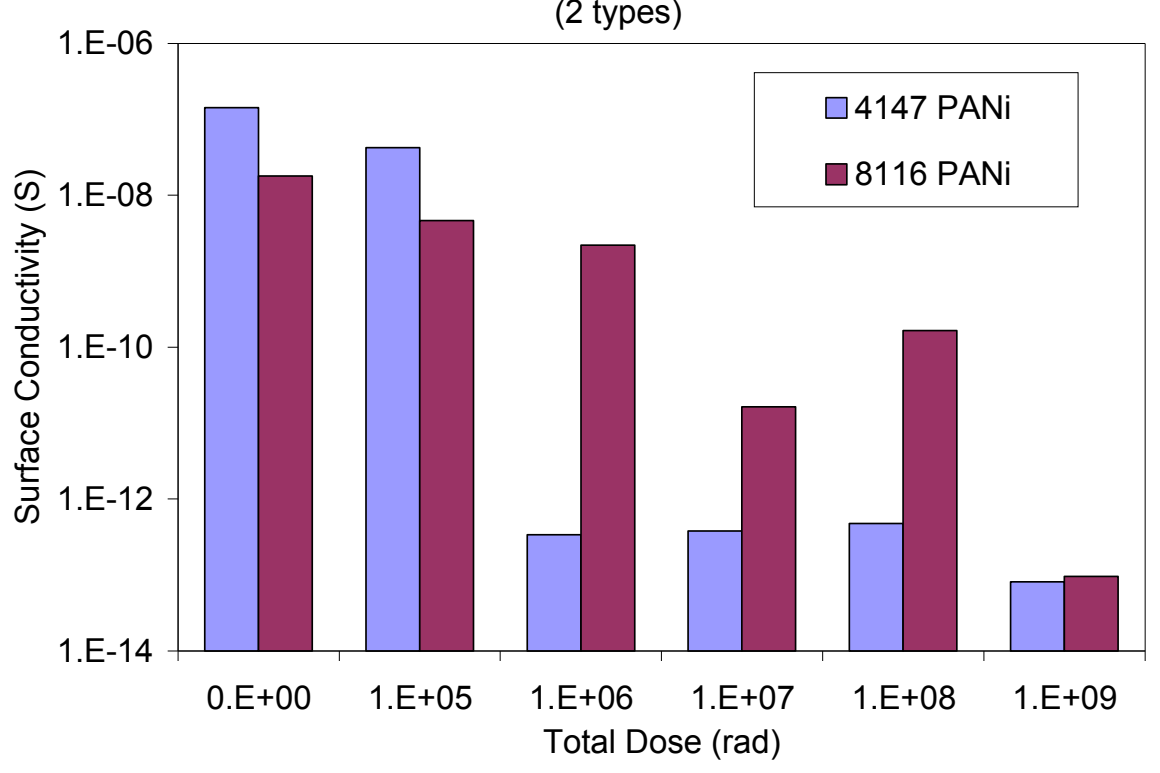

a.

Reduction in Conductivity with UV Exposure of PANi Polymer (2 types)

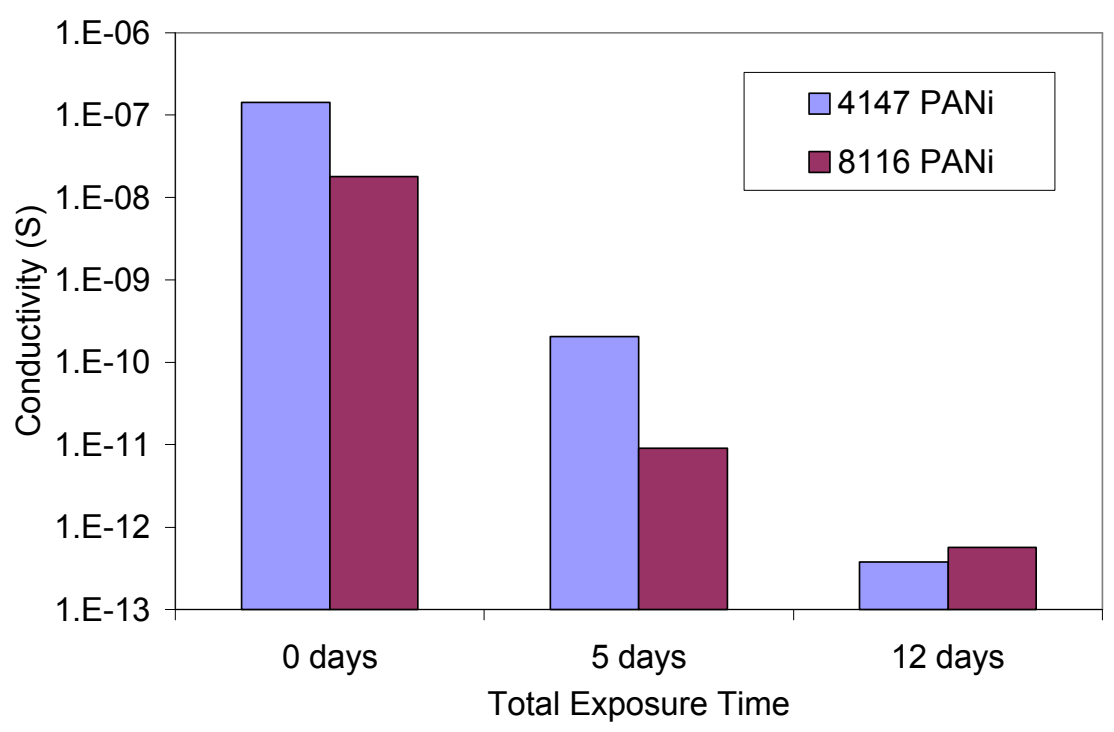

b.

Figure 10. a. Surface conductivity of two types of polyaniline as a function of total dose of ${ }^{60}$ Co gamma; $b$. Surface conductivity of two types of polyaniline as a function of time exposed to UV light at 168 $\mathrm{mW}$ 